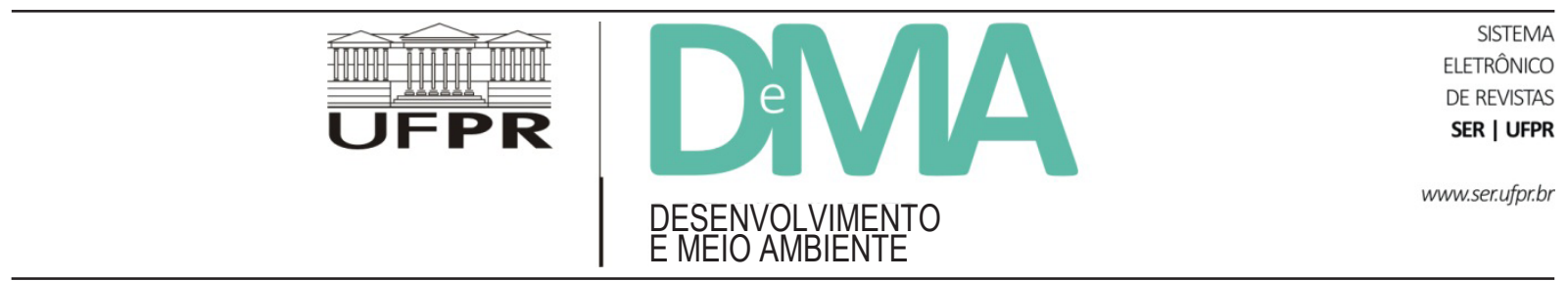

\title{
Vulnerability Among Fishers in Southern Brazil and its Relation to Marine Protected Areas in a Scenario of Declining Fisheries
}

\section{Vulnerabilidade de pescadores no litoral sul do Brasil e sua relação com áreas marinhas protegidas em um cenário de declínio da pesca}

\author{
Luiz Francisco Ditzel FARACO ${ }^{*}$, José Milton ANDRIGUETTO FILHO ${ }^{2}$, Tim DAW ${ }^{3}$, Paulo da Cunha LANA ${ }^{4}$, \\ Cristina Frutuoso TEIXEIRA ${ }^{5}$ \\ ${ }^{1}$ Instituto Chico Mendes de Conservação da Biodiversidade (ICMBio), Ministério do Meio Ambiente (MMA), Campo Largo, PR, Brasil. \\ ${ }^{2}$ Departamento de Zootecnia, Universidade Federal do Paraná (UFPR), Curitiba, PR, Brasil. \\ ${ }^{3}$ Stockholm Resilience Centre, Stockholm University, Sweden. \\ ${ }^{4}$ Centro de Estudos do Mar (CEM), Universidade Federal do Paraná (UFPR), Pontal do Paraná, PR, Brasil. \\ ${ }^{5}$ Departamento de Teoria e Fundamentos da Educação, Universidade Federal do Paraná (UFPR), Curitiba, PR, Brasil. \\ *E-mail of contact: xicofaraco@yahoo.com
}

Article received in March 11, 2016, final version accepted in July 11, 2016.

ABSTRACT: Vulnerability of small-scale fishers in the north coast of Paraná State, Southern Brazil, has been increasing due to a decline in catches and general problems of access to and management of natural resources, associated with biodiversity conservation policies. The predicted effects of climate change will represent an additional source of disturbance on local livelihoods. This study aimed to describe vulnerability of fishers and their adaptation strategies to ongoing reductions in catches, considered an analogue of possible responses to expected effects of climate change, and to evaluate the influence of no-take protected areas on them. Interviews were applied to 213 households, in 9 villages from Guaraqueçaba, in the Paranaguá Estuarine Complex. Results show that vulnerability varies in different spatial levels, mainly due to differences in the reliance on fisheries as a source of income, and in distribution of physical and social capital. Protected areas, if not adequately managed, can have a double negative effect on more vulnerable households, by restricting their access to mangrove resources in the present, and by limiting the viability of their favoured adaptation strategy for the future. These results are potentially useful for the development of biodiversity conservation and fisheries management actions adequate to the local level, and that contribute to reduce inequality and build resilience of fishers and the coastal ecosystems they rely on, in a scenario of declining fisheries and climate change.

Keywords: adaptive capacity; protected areas; mangroves; livelihoods; fisheries management. 
RESUMO: A vulnerabilidade socioambiental dos pescadores artesanais do litoral norte do Paraná vem aumentando devido à queda na disponibilidade de pescado e a problemas de acesso e gestão dos recursos naturais associados às atuais políticas de conservação. As mudanças climáticas previstas poderão ser fontes adicionais de impacto sobre os modos de vida das comunidades locais. Este trabalho teve como objetivo caracterizar a vulnerabilidade dos pescadores artesanais e suas estratégias de adaptação ao declínio da pesca, consideradas análogas a possíveis respostas aos efeitos futuros das mudanças climáticas, e avaliar o efeito das unidades de conservação sobre estes fatores. Foram feitas entrevistas em 213 domicílios, distribuídos em nove vilas do município de Guaraqueçaba, no Complexo Estuarino de Paranaguá. Os resultados indicam que há elevada variabilidade, em diferentes níveis da escala espacial, nos fatores que geram vulnerabilidade, determinada principalmente pelo nível de dependência em relação à pesca e pelo capital físico e social disponível. As áreas protegidas, caso não sejam adequadamente manejadas, podem afetar a vulnerabilidade dos pescadores duplamente, restringindo tanto o modo de vida atual quanto as opções de adaptação futura daqueles que já são mais vulneráveis. Os resultados dessa análise contribuirão para a adequação e a integração das políticas de gestão da pesca e de conservação da biodiversidade na zona costeira, como forma de promover a redução de desigualdades sociais e o aumento da resiliência conjunta de pescadores e dos ecossistemas costeiros, em um cenário de declínio da pesca e de mudanças climáticas.

Palavras-chave: capacidade adaptativa; unidades de conservação; manguezais; modos de vida; gestão pesqueira.

\section{Introduction}

Small-scale fishers base their livelihoods on highly variable and unpredictable natural resources (Allison \& Ellis, 2001). In addition to natural variability, small-scale fishers are subject to uncertainties and risks around management and access rights, and often limited financial and political support (Allison \& Ellis, 2001; Lam \& Pauly, 2010).

Although usually assumed to be poor and socially vulnerable, fishers are able to develop strategies to deal with this variability and sustain complex and diversified livelihoods (Cinner et al., 2012). In theory, livelihood diversification is a useful strategy to deal with variability both in the availability of resources and in sales of catches, therefore reducing risk (Ellis, 1998; Pomeroy et al., 2006). Livelihood diversification to reduce risk can be interpreted as one dimension of adaptive capacity, the ability to foresee disturbances, prepare for them, react to their arrival and adapt in the long-term (Brooks \& Adger, 2005; Brown \& Westaway, 2011). Adaptive capacity, combined with exposure and sensitivity to disturbances form the concept of vulnerability (e.g. Badjeck et al., 2010).

Adaptive capacity is difficult to study empirically as it is a latent ability, which is only mobilised in response to impacts. Empirical studies of adaptive capacity of fishing communities have therefore been based on hypothetical responses to future events (e.g. Daw et al., 2012), or assessing indicators of adaptive capacity derived from theory (e.g. Cinner et al., 2015). Few studies have connected predictors of adaptive capacity to empirical observations of adaptation behaviour in the face of disturbances.

As fisheries have increasingly impacted not only commercially explored species, but also marine biodiversity as a whole, overexploitation of resources is already considered one of the main causes of biodiversity loss (Nellemann et al., 2008). Climate change is expected to be a strong driver of additional changes in future decades with predicted reductions of fish stocks in tropical and subtropical coasts (Cheung et al., 2010), significant impacts on 
ecosystems and biodiversity, more disparity in food security between developing and developed countries, strong decreases in the value of landings and high human adaptation costs (Pörtner et al., 2014).

The establishment of marine protected areas (MPAs) is regarded as the most effective tool to conserve biodiversity (Dudley, 2008). MPA cover can be expected to rise rapidly considering that the marine realm is the one most distant from reaching the targets established in the Convention on Biological Diversity (Thomas et al., 2014). Such conservation actions can also affect fisheries livelihoods, restricting access rights and limiting adaptation and diversification options. If MPA establishment does not take into account social and economic aspects they can result in unequal distribution of costs and benefits, as seems to be the case of most existing protected areas (Adams \& Hutton, 2007; Cinner et al., 2014). Due to the lack of implementation and enforcement of many MPAs, non-compliance to restrictions can be seen as a strategy to deal with this situation, but it brings insecurity to livelihoods and cannot be regarded as a long-term solution (Cernea \& Schmidt-Soltau, 2006).

There are few published assessments of the combined impacts of MPAs, disturbance associated to declining fisheries and climate change on fishers' livelihoods. These combined effects need to be better understood in different scales, and taken into account in policy-making, management actions and livelihood adaptation strategies.

We have conducted a case study in nine villages from Guaraqueçaba, in the Paranaguá Estuarine Complex (PEC), Southern Brazil (Figure 1). This estuary is still home to well preserved coastal habitats, mostly protected by two no-take MPAs, Guaraqueçaba Ecological Station and Superagüi National Park, which have an important role in conserving coastal ecosystems and fisheries re- sources, mostly in mangrove habitats. It is also home to thousands of small-scale fishers, whose livelihoods rely heavily on coastal resources, many of which are located inside the protected areas. There is a shortage of official data on fisheries in the region, but the widespread perception of fishers is that catches have declined, a trend that is expected to intensify with climate change. Brazilian law recognizes that subsistence uses can be regulated inside no-take protected areas, but considers that ultimately these activities should stop or move to other areas, a solution that is often unfeasible and socially unacceptable. There is lack of enforcement and regulation of extractive uses, and open-access to resources.

We hypothesised that fishers' vulnerability and adaptive capacity to declines in catches will vary by communities due to different livelihood composition and proximity to protected areas. We aimed to describe vulnerability of fishers and their adaptation strategies to previous catch reductions and fluctuations, considered an analogue of possible responses to expected effects of climate change, and to evaluate the influence of no-take protected areas on them. For that we developed an index of vulnerability, tested for the influence of livelihood diversification on income and income variation, and investigated the relation between levels of adaptive capacity and the types of strategies considered by households to deal with a declining fisheries.

\section{Methods}

\subsection{Study site}

The Paranaguá Estuarine Complex has an area of $612 \mathrm{~km}^{2}$ and is characterized by strong salinity and energy gradients, with portions further inland 


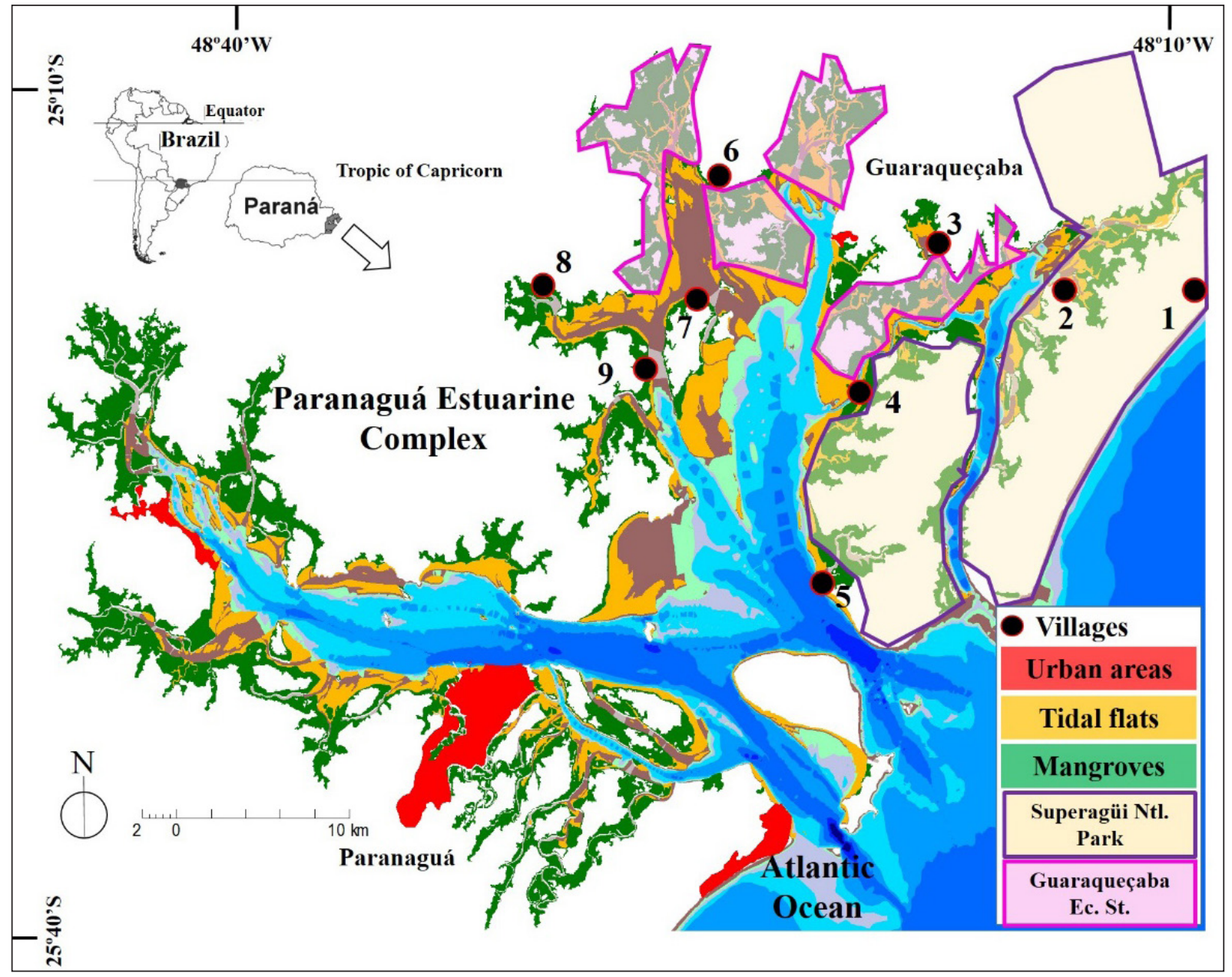

FIGURE 1 - Paranaguá Estuarine Complex, with the location of Protected Areas (Superagüi National Park and Guaraqueçaba Ecological Station), and the nine surveyed villages: 1. Barra do Ararapira; 2. Canudal; 3. Poruquara; 4. Guapicum; 5. Vila das Peças; 6. Tromomô; 7. Ilha Rasa; 8. Engenho Velho; 9. Massarapuã.

being heavily influenced by rainfall and continental water inflow (Lana et al., 2001). Storms and freshwater input affect fishing activities, limiting the number of fishing days and "pushing" valuable species, such as prawns, out of the estuary, leaving them inaccessible for those that can't fish in open waters due to lack of proper boats and gear. There are no local-scale climate-change models or predictions for the coast of Paraná. A regionalization of continental models for the $21^{\text {st }}$ century indicates an increase in average surface temperatures for the south and southeast of Brasil and, with higher levels of uncertainty, an increase in rainfall for the subtropical part of the country (Marengo \& Valverde, 2007).

The coast of Paraná is part of Brazil's Atlantic Forest Biome, one of the world's biodiversity hotspots, with Guaraqueçaba holding around $80 \%$ 
of its original forest cover (Fundação SOS Mata Atlântica/INPE, 2015), compared to an average of only 7,5\% for the biome as a whole (Myers, 2000). Estuaries in the region have extensive tidal flats, largely covered by around $182 \mathrm{~km}^{2}$ of wellpreserved mangrove forests, an important source of fisheries products, such as crabs (Ucides cordatus) and oysters (Crassostrea rhizophorae). A survey of catches conducted during one year estimated a total production of 11,000 dozens of crabs and 38,000 dozens of oysters for the region (IPÊ, 2011).

The 9 villages surveyed (Table 1) were selected based on three criteria: distance to a no-take MPA (inside/near/far); size (small/medium/large, following Andriguetto-Filho, 2002) and existence and quality of data on fish catches, mainly from surveys conducted in 2009 (IPÊ, 2011). This selection aimed to represent the diversity of settings found in the region. Villages were considered near a MPA when located immediately adjacent to either the National Park or the Ecological Station. Villages were also classified according to the predominant technical fishing system (Andriguetto-Filho, 2003), with most of them being typical of System II, characterized by a variety of gears, techniques and target species, but with fishers working only inside the estuary. Only Barra do Ararapira and Vila das
Peças are part of System III, where shrimp is the main target species, captured with bottom trawling both inside and outside the estuary.

General socioeconomic information about the region is available in National Census publications (IBGE, 2011). Guaraqueçaba is the least populated (around 7,800 inhabitants) and the poorest municipality in the coast of Paraná, with a Human Development Index (IDH-M) of 0,587 (IPARDES, 2016). While industrial fishing is predominant in southern and southeastern Brazil, most of the catches in Paraná come from small-scale fisheries. The activity is socially relevant for food security and livelihoods because of the number of people involved, but contributes little to the regional economy (Borges et al., 2004). There are around 1,100 professional small-scale fishers in Guaraqueçaba (AndriguettoFilho et al., 2006), though records are imprecise and numbers vary. Main target species are prawns, such as Litopenaeus schimitii and Xiphopenaeus kroyeri, and crabs, specially the mangrove crab (U. cordatus) and the blue crab (Callinectes danae). Among fish, the mullet Mugil platanus has special relevance.

Due to the general decline in fish stocks, collecting crabs and oysters in mangroves has increased in importance in the past years (Miranda, 2004). They have become the main fisheries activity and an

TABLE 1 - Main characteristics of surveyed villages.

\begin{tabular}{lcccc}
\hline \multicolumn{1}{c}{ VILLAGE } & HOUSEHOLDS (TOTAL) & INTERVIEWS & $\begin{array}{c}\text { DISTANCE } \\
\text { TO MPA }\end{array}$ & $\begin{array}{c}\text { FISHING } \\
\text { SYSTEM }\end{array}$ \\
\hline VILA DAS PEÇAS (5) & 59 (Large) & 46 & Near & III \\
ILHA RASA (7) & 54 (Large) & 48 & Far & II \\
BARRA DO ARARAPIRA (1) & 44 (Medium) & 40 & Inside & III \\
TROMOMÔ (6) & 31 (Medium) & 29 & Near & II \\
MASSARAPUÃ (9) & 20 (Medium) & 18 & Far & II \\
GUAPICUM (4) & 13 (Medium) & 12 & Near & II \\
PORUQUARA (3) & 13 (Medium) & 11 & Near & II \\
CANUDAL (2) & 6 (Small) & 5 & Inside & II \\
ENGENHO VELHO (8) & 5 (Small) & 4 & Far & II \\
\hline
\end{tabular}


important source of income for many households in some of the System II villages, increasing pressure on MPAs, while collection for local consumption is culturally important in most of the region.

Being part of a biodiversity hotspot, Guaraqueçaba is regarded as a priority region for biodiversity conservation actions, with around $75 \%$ of the coast of Paraná already designated as protected areas. Conservation actions increased in the region in the 1980 s, with the creation of protected areas and the arrival of environmental NGOs. This was also a period when Brazil's environmental laws started becoming more rigorous, specially regarding deforestation of the Atlantic Forest (Andriguetto-Filho, 1993). Meanwhile, many fisheries management rules were created, mostly based on a centralized, top-down system, and lacking proper enforcement and evaluation. This set of conservation and management actions has variously impacted regional livelihoods, and is regarded by many locals as one of the main causes of the region's social and economical difficulties. This view is disputed by most environmental agencies and NGOs. Nevertheless, there has been constant resistance of local populations against protected areas and fisheries management rules in the region (e.g. Zanoni et al., 2000; Teixeira, 2005).

The two no-take PAs analyzed in this study were the Guaraqueçaba Ecological Station, created in 1982 to conserve around 5,000 hectares of mangroves in the northern part of the estuary, and Superagüi National Park, created in 1989 to protect 34,000 hectares of beaches, lowland forests and mangroves (Figure 1).

\subsection{Data collecting}

A survey was conducted between January and May 2011, covering 213 households in the 9 villages (Table 1), with two types of structured and semi-structured interviews - a household survey and a key-informant survey - complemented with secondary data and general observations of village characteristics. All households were visited, with the aim of conducting a census-type survey reaching all resident families. A coverage of $87 \%$ was achieved, with the remaining residents being either absent during the period of the survey or unwilling to participate. Key-informants (usually one per village) were identified based on previous knowledge about village organization and on citations by other residents.

\subsection{Data processing}

This study followed the "contextual vulnerability' approach, which aims to identify how socioeconomic, political and ecological contexts influence, in the present, levels of vulnerability and the possibilities for adaptation to current and future threats related to environmental change (Kelly \& Adger, 2000). Inferences about future adaptation are based on the comprehension of current vulnerability, through the analysis of past and present experiences of contact with and responses to different types of disturbances. These responses are treated, in this approach, as temporal analogues to possible adaptations to expected effects of future disturbances, including climate change (Ford et al., 2010). In our case, the considered threat was the predicted intensification in the decline of fish catches for tropical and subtropical coastal areas (Cheung et al., 2010). The fact that fishers are already experiencing this decline provided the opportunity to analyze how elements of the social system (socioeconomic characteristics of household and villages, and conservation actions represented by 
no-take protected areas) influence fishers' capacity to explore natural resources and adapt to changes and disturbances related to this resource base.

Methods followed three steps, shown in Figure 2: description of vulnerability, with the use of a numerical index and multivariate analyses, aiming to identify general patterns and differences among households and villages; analysis of relations between diversification, income and exposure to risk, aiming to assess the role of livelihood diversification in reducing vulnerability; and comparison of the effect of no-take protected areas on the adaptation options of households with different levels of adaptive capacity, using information on strategies adopted or planned by households to diversify outside of fisheries and deal with a decline in catches.
Vulnerability indexes are usually constructed using indicators of sensitivity, such as reliance on fisheries (Allison et al., 2009; Cinner et al., 2012), combined with the exposure to specific threats, such as natural disasters and climate variability (Schwarz et al., 2011), and with several different elements that are considered determinants of adaptive capacity (e.g. Yohe \& Tol, 2002; Tuler et al., 2008; Kalikoski et al., 2010). Due to the lack of in-depth information on the predicted impacts of climate change on local fishing resources, and considering that villages surveyed are located in a relatively small and homogeneous area, exposure to decline in catches was considered the same for the whole region. Sensitivity was characterized as the reliance on fisheries, while adaptive capacity was

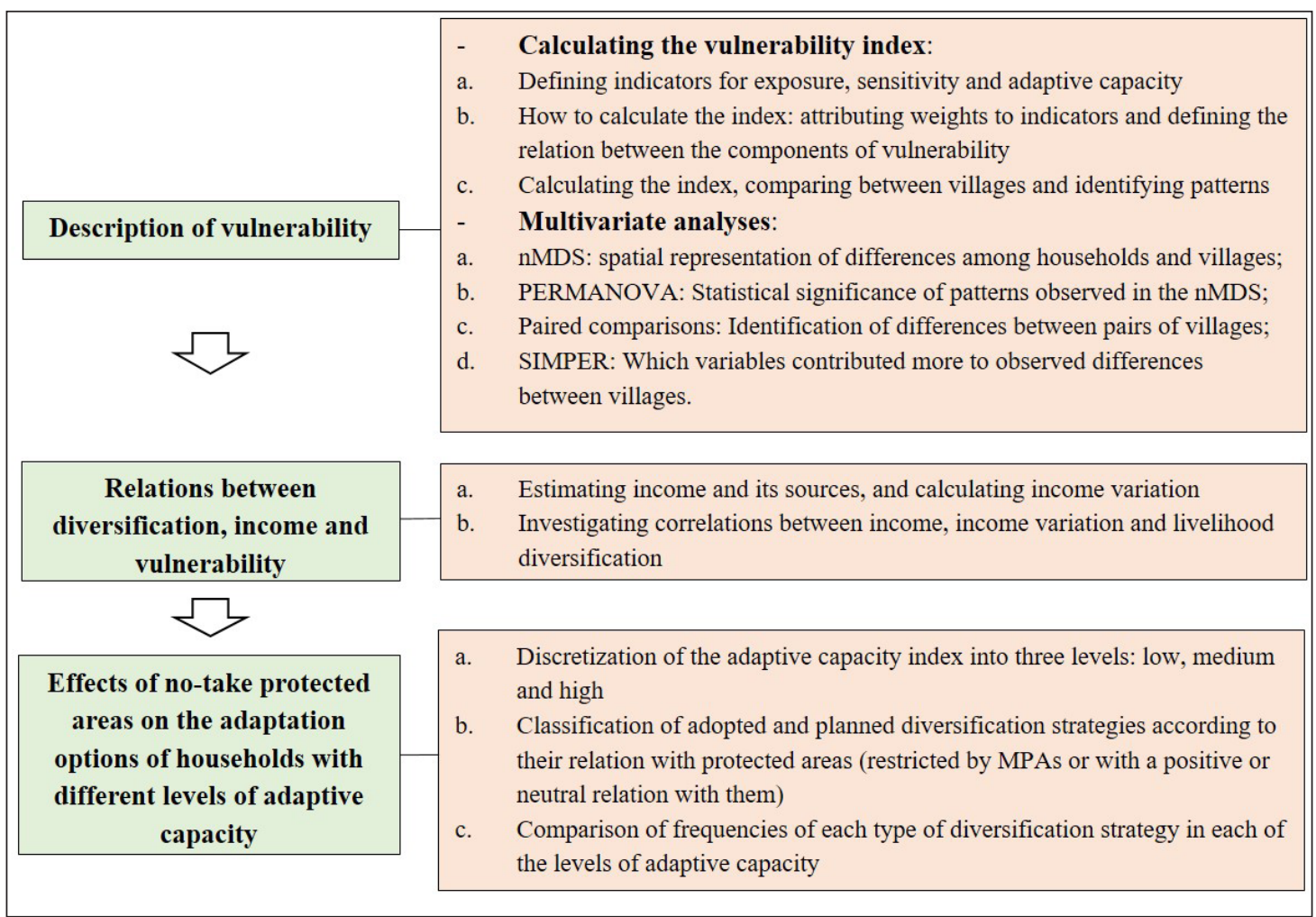

FIGURE 2 - Outline of methodological steps and substeps adopted in the analysis. 
measured based on the types of capital available and diversity of local livelihoods (Chambers \& Conway, 1992; Ellis, 2000; Allison \& Ellis, 2001). Selection of indicators was based on studies mentioned in this section, with adaptations to the reality of the northern coast of Paraná (Table 2). Past and future adaptation strategies to deal with the decline in fish catches were measured independently and used in the third step of the analysis. Present diversity of livelihood activities and diversity of fisheries, used here as indicators of adaptive capacity, may have been influenced by the adaptation strategies adopted in the past, introducing some circularity to the analysis, but that does not affect the analysis of strategies considered by households for future adaptation.

Two methods were used to characterize differences in vulnerability among villages and households: a numerical index of vulnerability, calculated as an average of the sensitivity and adaptive capacity indicators described in Table 2, which allowed identification of general patterns; and the following multivariate analyses: nMDS (Clarke, 1993), PERMANOVA (Anderson, 2001), paired comparisons and SIMPER (Clarke, 1993), to test for differences in vulnerability among villages and households, considering each variable (indicator) and sample (household) separately, allowing identification of internal variability of vulnerability in villages and of the role of each indicator in determining different levels of vulnerability. Analysing each variable separately is important for a better description of threats to specific elements that are valuable to people (Luers et al., 2003).

Households that had no answers for any one of the indicators had to be eliminated in the multivariate analysis, resulting in a subset of 132 households. These analyses were performed using PRIMER software, version 6.1.6. The statistical significance threshold for all analyses was $\mathrm{p}<0.05$. The indicators in the vulnerability index were normalized between values of 0 and 1 .

Considering the lack of background information available to define weights to each indicator, we calculated sensitivity and adaptive capacity as the average of the unweighted indicators (Hahn et al., 2009). For the indicators that contribute negatively to adaptive capacity $(\mathrm{d}, \mathrm{f}, \mathrm{g}$ and $\mathrm{q}$, from Table 2), values were subtracted from 1 before the index was calculated. Thus: Sensitivity $(S)=(a+$ $b+c) / 3$ and Adaptive capacity $(A C)=((1-d)+e$ $+(1-f)+(1-g)+h+i+j+k+l+m+n+o$ $+p+(1-q)+r+s+t) / 17$.

Because little is known about the nature of the interaction between the components of vulnerability (Allison et al., 2009), we treated them as equally important and calculated vulnerability as an average of sensitivity and adaptive capacity, with the latter being inverted, so that the village or household with the higher level of adaptive capacity would end up with lower vulnerability: Vulnerability $(V)=(S+$ $(1-C A)) / 2$.

To analyze the relation between vulnerability and livelihood diversification, the influence of diversification (of livelihoods and of fisheries) on income and income variation was investigated using ranked Spearman's correlation. Income variation was considered a surrogate for risk because greater variation of income throughout the year means a household is more exposed to food insecurity and less able to save money and invest. Income was assessed individually for each household and income sources were separated in six main groups: fisheries; fisheries from mangroves; cultivation (agriculture and aquaculture); businesses; paid jobs; pensions and governmental benefits. This grouping was based on a first level division between fisheries and non-fisheries sources, and a further division 
TABLE 2 - Indicators of sensitivity and adaptive capacity, divided in subcomponents and classified according to the type of capital (human, social, natural, physical or financial), their contribution to the sensitivity and adaptive capacity indexes (positive or negative) and the level (household or village) in which data was considered in calculations.

\begin{tabular}{lcc}
\hline $\begin{array}{c}\text { Vulnerability } \\
\text { component and } \\
\text { subcomponent }\end{array}$ & Indicator & $\begin{array}{c}\text { Contribution to } \\
\text { index }\end{array}$ \\
\hline SENSITIVITY & & Source of data
\end{tabular}

Economic reliance on fisheries

\section{ADAPTIVE CAPACITY}

(a) $\%$ of income coming from fisheries

(b) $\%$ of households with fisheries as main source of income

(c) $\%$ of households with fisheries as only source of income

Natural capital

(d) \% of income from mangroves (protected areas)

$\begin{array}{ll}\text { positive } & 1 \\ \text { positive } & 2 \\ \text { positive } & 2\end{array}$

negative 1

Human capital - education, demography and health

(e) Average, with different weights*, of two subindicators: years of study of adult ( $>17$ yrs old) with higher education level in household (2/3) and

$\begin{array}{ll}\text { positive } & 1^{\text {st }} \text { subindicator: } 1 \\ 2^{\text {nd }} & \text { subindicator: } 2\end{array}$

$\%$ of households in which children are in school (1/3)

(f) Dependency ratio **

(g) \% of households in which people have missed school or work due to health problems in the past 30 days

negative

1

negative

2

Physical capital - technology and infrastructure

(h) Food storage capacity ***

(i) Diversity of fishing gear

(j) Number of motorboats

(k) Socioeconomic development index ****

$\begin{array}{ll}\text { positive } & 1 \\ \text { positive } & 1 \\ \text { positive } & 1 \\ \text { positive } & 2\end{array}$

Social capital - community organization, market connections

(1) number of community organizations (includes churches)

(m) proportion of existing community organizations in which household members participate

(n) number of market connections the household has $* * * * *$

(o) proportion of households with market connections outside the village

positive

positive

2

positive 2

Financial capital - resource availability, income variability and total income

(p) difference between income and expenditures

(q) income variation among months, during one year

(r) total annual income

positive

1

positive

negative

positive

1

1

2

\section{Livelihood diversity}

(s) diversity of fisheries practiced by household members

(t) diversity of activities that compose household livelihood

\begin{tabular}{ll} 
positive & 1 \\
positive & 1 \\
\hline
\end{tabular}

\footnotetext{
* Weighting based on UNDP (2003).

** proportion of household members that are economically active; measured as the ratio between number of members under 15 or over 65 and number of members between 18 and 65 yrs (Hahn et al., 2009).

*** storage means were divided and classified according to increasing capacity to preserve food, in a $0-1$ scale: 0 , for those households that have no means of storing their catches; 0.25 , for those that use artisanal methods of smoking or salting fish, or use ice; 0.50 , for those that use both smoking/salting and ice; 0.75 , for households that have a fridge; and, 1.00 , for households that have a freezer.

**** calculated according to presence or absence of the following infrastructure in the village: primary school; secondary school; high school; university-level courses; hospital; doctor visiting at least once a month; market; restaurant; hotel/guesthouse; electricity; regular transportation to nearest town; churches; community organizations.

***** number of different people or places to which households sell their catches.

Source of data coded as $1=$ Variables collected or calculated at household level and $2=$ Variables collected or calculated at village level.
} 
between resources coming from inside or outside protected areas (mangroves) in the first group, and the security derived from the source of income in the second group (paid jobs and pensions being considered more secure than businesses). Income values among villages were compared using a Kruskal-Wallis test. The coefficient of income variation over the year for a given household was calculated as the standard deviation divided by the mean and was used both as an indicator of adaptive capacity ( $q$, in Table 2$)$ and as a dependent variable in the second step of the anaysis.

To test the effect of MPAs on adaptation options of households with different levels of adaptive capacity we first categorized the types of diversification strategies adopted or planned by villagers. Strategies of diversification outside of fisheries (considered to be the most efficient in reducing exposure to risk, and therefore, vulnerability), were separated into two categories: restricted by MPAs (R); and with a positive or neutral relation with them (PN). Restricted were those involved in extraction of mangrove resources, mainly oysters for cultivation (for all villages), or that required interventions in areas inside MPAs, such as agriculture and fish or shrimp cultivation (in this case, only if villages were located inside or adjacent to MPAs). Strategies classified as positively affected or neutral were those involving activites outside MPAs, or, if inside, those which are theoretically favoured by the existence of a protected area, such as tourism. In households where more than one type of strategy was mentioned, the classification corresponded to the one with the higher frequency, i.e. if one restricted strategy and two positively affected or neutral were mentioned, the household was classified as PN.

The adaptive capacity index values - initially a continuous variable - were grouped into three discrete groups: low, medium and high adaptive capacity. Discretization was done following methods described in Fernandes et al. (2010).

We then compared strategies adopted (past and present) and considered (future) by households to deal with the fall in fish catches according to the level of adaptive capacity and their relation with protected areas.

\section{Results}

\subsection{Variability in vulnerability among households and villages}

Calculation of the index of vulnerability and its components (sensitivity and adaptive capacity) revealed a general pattern of variability in different levels of the spatial scale: inside villages, among villages and in the region as a whole (Figure 3 ). This variability in values suggests several of the factors that compose the indicators are important in determining differences in vulnerability. Canudal stands out as high sensitivity - presumably because almost entirely fishery dependent. While most villages had intermediate values, Vila das Peças, the largest village, had lower sensitivity and higher adaptive capacity. The vulnerability index followed this pattern, with a group of villages having intermediate and similar values, while Canudal and Guapicum (higher vulnerability) and Massarapuã and Vila das Peças (lower vulnerability) had more extreme values.

The nMDS (Figure 4) also highlighted internal variability in many of the villages and indicates differences among villages. The PERMANOVA indicated significant differences between villages (Pseudo-F= 7.2386; P (perm) $=0.0001$; numb. Permutations $=9890$ ), and, together with the paired 


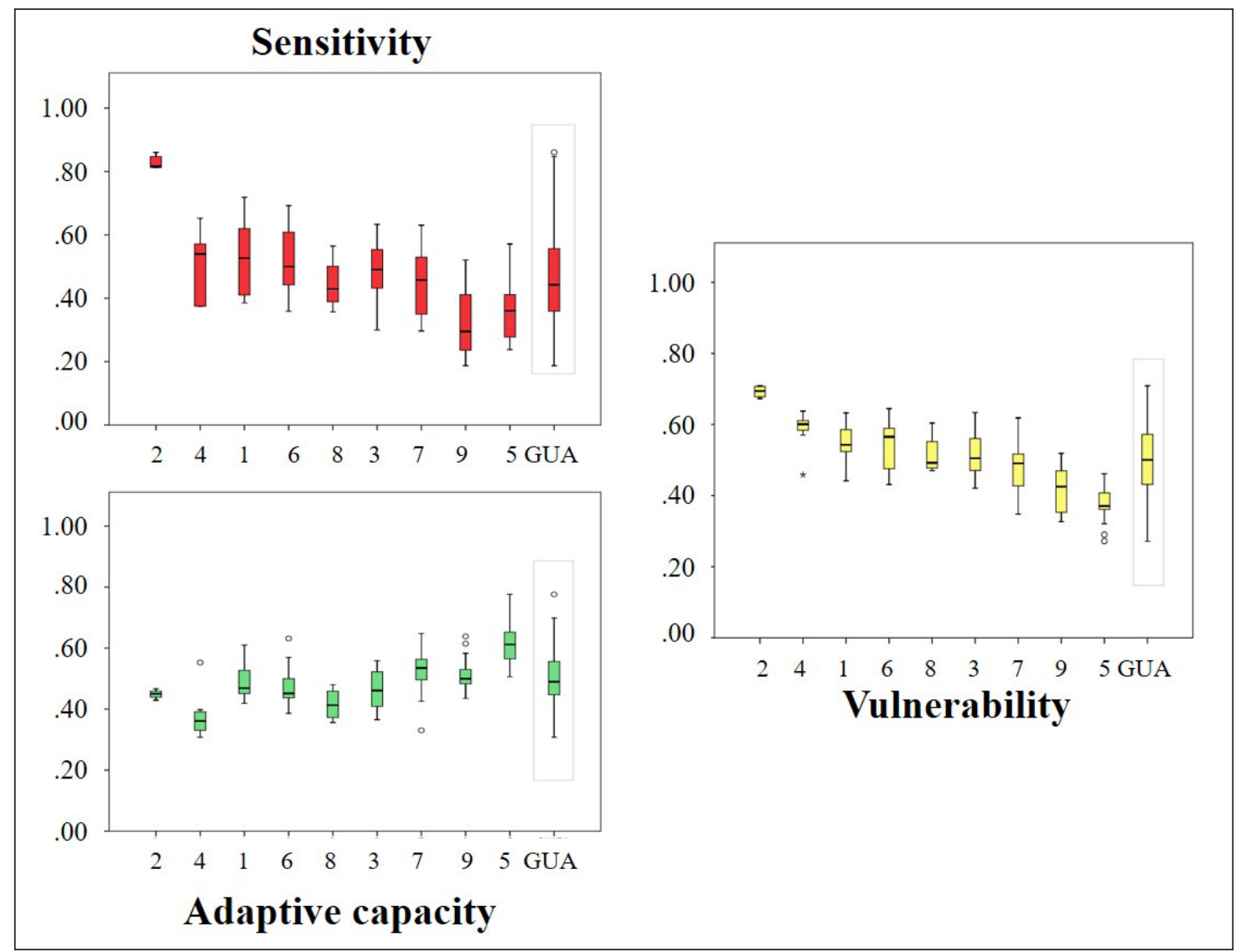

FIGURE 3 - Distribuiton of vulnerability, sensitivity and adaptive capacity values, inside each village and among villages. Villages are shown from higher to lower vulnerability: $2=$ Canudal, $4=$ Guapicum, $1=$ Barra do Ararapira, $6=$ Tromomô, $8=$ Engenho Velho, 3 = Poruquara, 7 = Ilha Rasa, 9 = Massarapuã e 5 = Vila das Peças. The last boxplot (GUA) shows distribution considering all surveyed households.

comparisons, showed a division between two groups of villages, separated on the nMDS with a red line.

Group 1 is formed by Canudal (2), Guapicum (4), Engenho Velho (8) and Poruquara (3), with most households distributed on the left side of the graph; and Group 2, by Vila das Peças (5), Tromomô (6), Ilha Rasa (7) and Massarapuã (9), on the right. Barra do Ararapira (1) didn't fall into any of the groups, possibly because of higher internal variation in comparison to other villages.
The SIMPER analysis allowed for the identification of the variables that contributed the most to observed differences (Table 3). The most important one was storage capacity (h), responsible for 30 to $50 \%$ of the observed differences. This is mostly related with differences in availability of electricity in the two groups of villages. Other important factors were the higher reliance on fisheries and greater income variation observed in villages in Group 1. Not all indicators were lower in these villages, e.g. they had a higher proportion of motor boats and of 


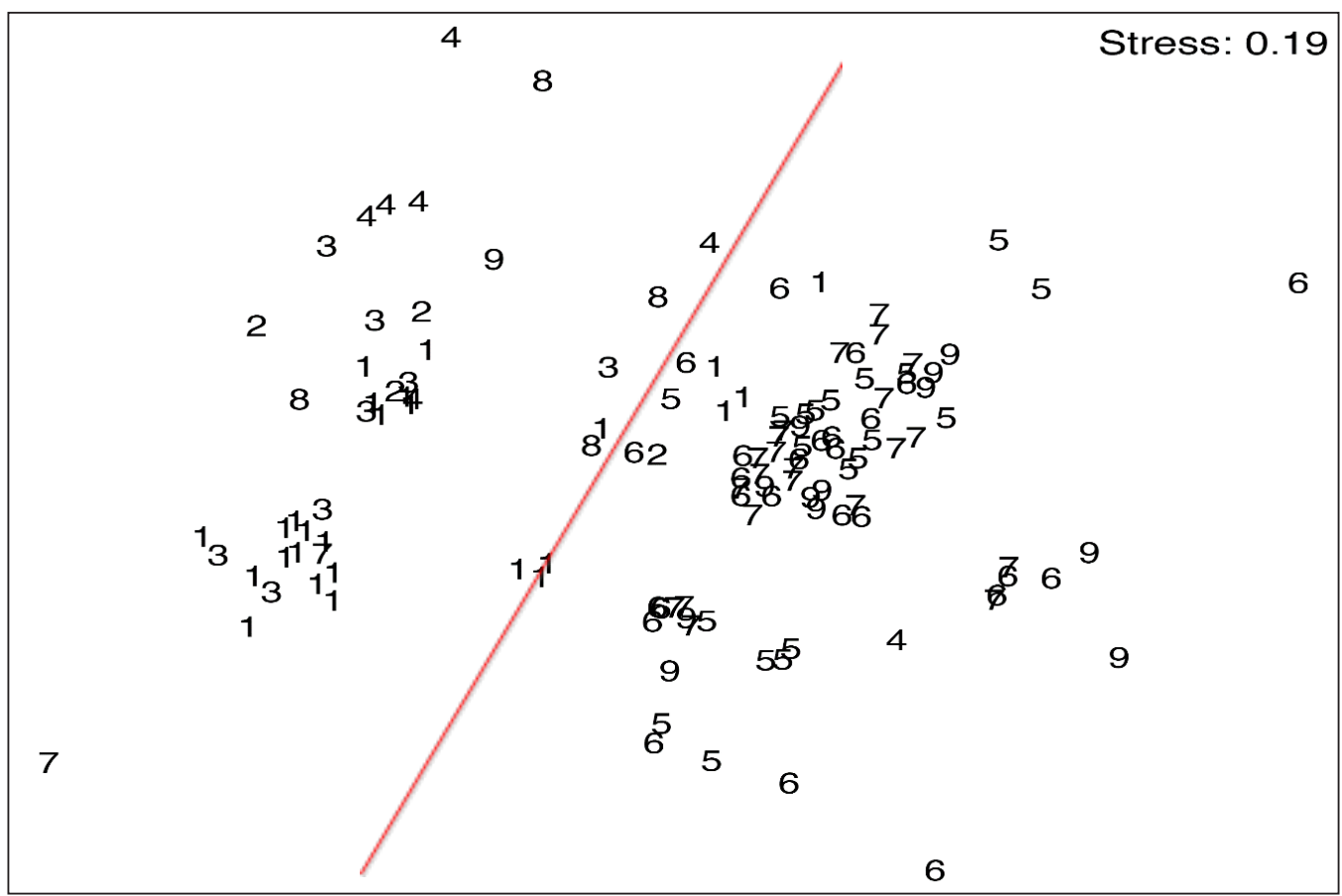

FIGURE 4 - Results of the nMDS analysis. Each number represents a household and identifies the village. Distribution on the graph is determined by the 14 indicators of sensitivity and adaptive capacity measured on the household level. 1= Barra do Ararapira, 2= Canudal, 3= Poruquara, 4= Guapicum, 5=Vila das Peças, 6= Tromomô, 7= Ilha Rasa, 8= Engenho Velho and $9=$ Massarapuã.

participation in community organizations - except Guapicum. On the other hand, villages in Group 2, which were, on average, less dependent on fisheries, showed higher gear diversity, although concentrated on a few households.

\subsection{Income, diversification and risk}

Despite different values of average income in different villages (Canudal mean income was less than half of income in Poruquara, Barra do Ararapira and Tromomô), statistical analysis showed no significant differences between villages, likely due to high inequality in income between rich and poor households in the same village, as shown by the wide ranges of income within each village and rich/poor income ratios varying from 2.4 to 10.3 (Table 4).

Although all villages had a majority of households conducting fisheries, only in Canudal, Engenho Velho and Poruquara did fisheries represent more than $50 \%$ of income (Figure 5). In the other villages, different sources of income were important, specially governmental benefits (pensions, minimum wage programs, fishing ban compensations), but also paid jobs, businesses and oyster cultivation, with fisheries appearing as the main source for roughly half of the households. 
TABLE 3 - Representation of the SIMPER results, indicating which variables contributed most to observed differences between villages. Codes for variables are: storage = storage capacity; boats = number of motor boats; community = participation in community organizations; market $=$ market connections; inc. var. $=$ income variation; gear = gear diversity; inc. mang. $=\%$ of income from mangroves; inc. fish. $=\%$ of income from fisheries; inc.exp. $=$ difference between income and expenditures; $e d u=$ education. Variables are shown in decreasing order of importance. Underlined variables explain at least $60 \%$ of observed diferences. Number after variable indicates village in which values were higher. Empty cells indicate no significant difference between pair of villages. Red= Group 1; Green= Group 2 .

\begin{tabular}{|c|c|c|c|c|c|c|c|c|c|}
\hline Can (2) & Can (2) & & & & & & & & \\
\hline Gua (4) & & Gua (4) & & & & & & & \\
\hline Eng (8) & & & Eng (8) & & & & & & \\
\hline Por (3) & & & & Por (3) & & & & & \\
\hline Bar (1) & 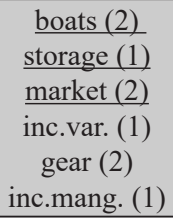 & $\begin{array}{l}\frac{\text { community }}{(1)} \\
\text { boats (4) } \\
\text { storage (1) } \\
\text { inc.exp. (1) }\end{array}$ & $\begin{array}{l}\frac{\text { boats }(8)}{\text { community }} \\
\frac{(1)}{\text { gtorage }(8)} \\
\text { gear }(1)\end{array}$ & & Bar (1) & & & & \\
\hline Tro (6) & $\begin{array}{l}\frac{\text { storage (6) }}{\text { community }} \\
\frac{(2)}{\text { market }(2)} \\
\text { boats (2) } \\
\text { inc.fish. (2) }\end{array}$ & $\begin{array}{l}\frac{\text { storage }(6)}{\text { community }} \\
\frac{(6)}{\text { boats }(4)} \\
\text { inc.exp. (6) }\end{array}$ & $\begin{array}{l}\frac{\text { storage }(6)}{\text { community }} \\
\frac{(8)}{\text { boats }(8)} \\
\text { inc.fish. (8) }\end{array}$ & $\begin{array}{l}\frac{\text { storage (6) }}{\text { community }} \\
\frac{(3)}{\text { boats }(6)} \\
\text { inc.fish. (3) } \\
\text { gear (6) }\end{array}$ & $\begin{array}{c}\frac{\text { storage (6) }}{\text { boats (6) }} \\
\text { community (1) } \\
\end{array}$ & $\begin{array}{l}\text { Tro } \\
\text { (6) }\end{array}$ & & & \\
\hline $\operatorname{Ras}(7)$ & $\begin{array}{l}\frac{\text { storage (7) }}{\text { market (2) }} \\
\underline{\text { boats }(2)} \\
\text { community } \\
(2) \\
\text { inc.var. (7) }\end{array}$ & $\begin{array}{l}\frac{\text { storage }(7)}{\text { community }} \\
\frac{(7)}{\text { boats (4) }} \\
\text { inc.exp. (7) }\end{array}$ & $\begin{array}{l}\frac{\text { storage }(7)}{\text { community }} \\
\underline{(8)} \\
\text { boats }(8)\end{array}$ & $\begin{array}{l}\frac{\text { storage }(7)}{\text { boats }(7)} \\
\frac{\text { community }}{(3)} \\
\text { edu (7) }\end{array}$ & $\begin{array}{l}\frac{\text { storage (7) }}{\text { boats (7) }} \\
\text { community (1) } \\
\text { gear (7) }\end{array}$ & & $\operatorname{Ras}(7)$ & & \\
\hline Mas (9) & $\begin{array}{l}\frac{\text { storage (9) }}{\text { market (2) }} \\
\frac{\text { community }}{(2)} \\
\text { boats (2) } \\
\text { inc.var. (9) } \\
\text { inc.fish. (2) }\end{array}$ & $\begin{array}{l}\frac{\text { storage }(9)}{\text { community }} \\
\frac{(9)}{\text { boats }(4)} \\
\text { inc.exp. (9) }\end{array}$ & $\begin{array}{l}\frac{\text { storage (9) }}{\text { community }} \\
\frac{(8)}{\text { boats }(8)} \\
\text { gear (9) } \\
\text { inc.fish. (8) } \\
\text { inc.var. (8) }\end{array}$ & $\begin{array}{l}\frac{\text { storage (9) }}{\text { boats (9) }} \\
\text { community } \\
\text { (3) } \\
\text { inc.fish. (3) }\end{array}$ & $\begin{array}{l}\text { storage (9) } \\
\text { boats (9) } \\
\text { community (1) } \\
\text { inc.var. (1) } \\
\text { inc.fish. (1) }\end{array}$ & & & Mas (9) & \\
\hline
\end{tabular}


TABLE 4 -Average per capita monthly income, income variation and diferences in income between $10 \%$ poorer and $10 \%$ richer households in each village. "Rich" and "poor" in this case relate only to the monthly income of each household.

\begin{tabular}{lccc}
\hline Village & $\begin{array}{c}\text { Average } \\
\text { monthly } \\
\text { per capita } \\
\text { income (R\$) }\end{array}$ & $\begin{array}{c}\text { Range of monthly } \\
\text { income values } \\
\text { (R\$) }\end{array}$ & $\begin{array}{c}\text { Rich/ } \\
\text { poor } \\
\text { (ratio) }\end{array}$ \\
\hline Tromomô & 466.23 & $168.21-1,580.00$ & $7.7 \mathrm{X}$ \\
$\begin{array}{l}\text { Barra do } \\
\text { Ararapira }\end{array}$ & 442.62 & $100.83-1,518.33$ & $10.3 \mathrm{X}$ \\
Poruquara & 402.15 & $197.92-591.11$ & $3.0 \mathrm{X}$ \\
Guapicum & 379.88 & $91.29-843.75$ & $9.2 \mathrm{X}$ \\
Massarapuã & 371.00 & $137.33-902.22$ & $6.0 \mathrm{X}$ \\
Vila das Peças & 364.17 & $78.75-1,028.75$ & $8.0 \mathrm{X}$ \\
Ilha Rasa & 333.29 & $117.20-931.04$ & $5.6 \mathrm{X}$ \\
Engenho & 302.77 & $122.92-688.96$ & $5.4 \mathrm{X}$ \\
Velho & 201.89 & $109.60-265.56$ & $2.4 \mathrm{X}$ \\
Canudal & & &
\end{tabular}

The number of households that had fisheries as the only source of income ranges from $80 \%$ in Canudal (2) to $40 \%$ in Tromomô (6) and Barra do Ararapira (1), and less than $20 \%$ in Poruquara (3) and Massarapuã (9).

The importance of mangrove resources was also variable. In some villages, such as Canudal (2) and Engenho Velho (8), oysters and crabs represented around $30 \%$ of total income, while others, such as Vila das Peças and Barra do Ararapira had no income from these resources.

Households with fisheries as the main source of income appeared in both the high and the low income groups of households, although this condition is more frequent among the low income ones. Also, in both there are those that explore mangrove resources. Among the lower income households

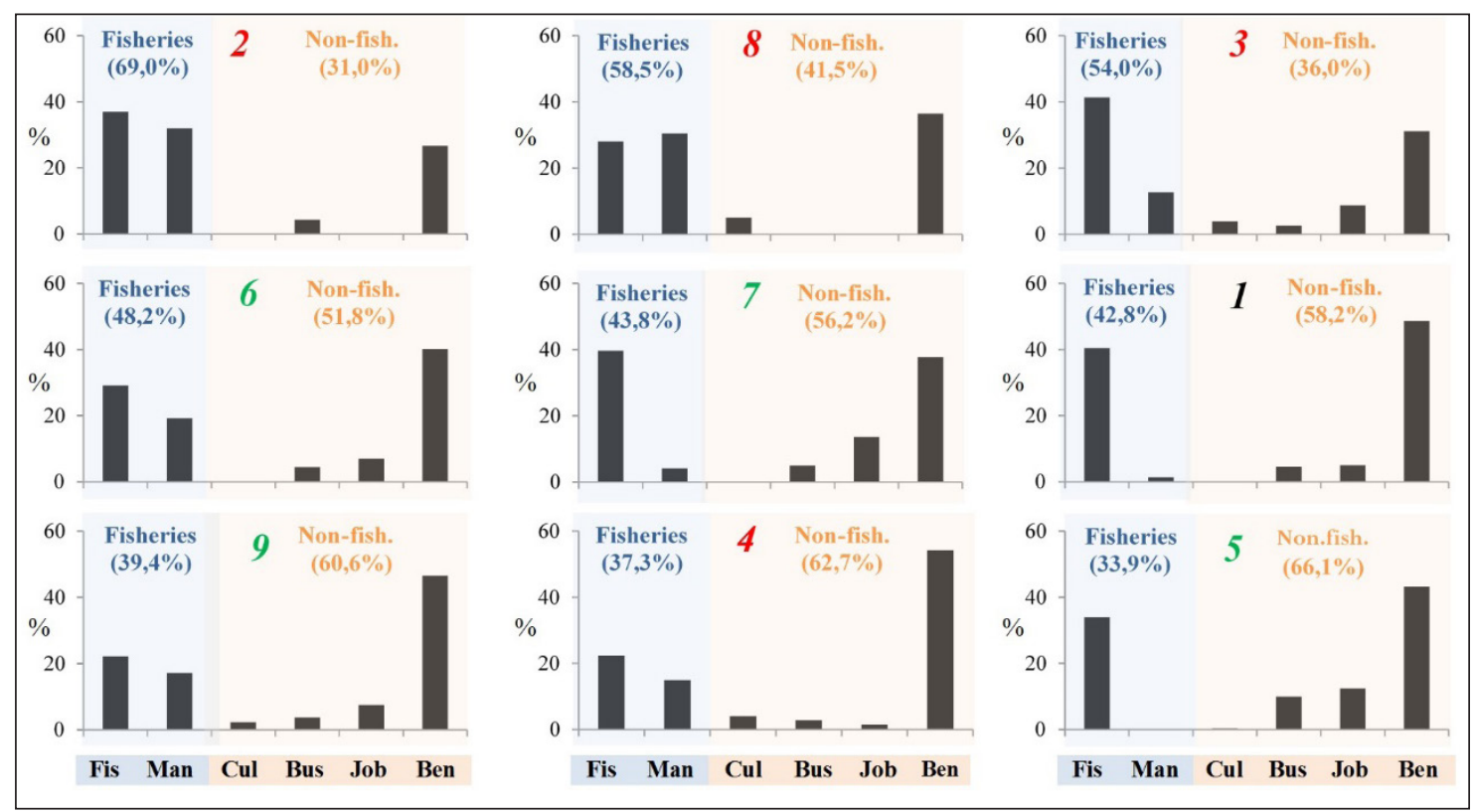

FIGURE 5 - Differences in income composition among villages. $y$-axis = percentage of total income coming from each source. Sources are divided in: Fis = fisheries, excluding mangrove resources; Mang = mangrove resources; Cul= oyster cultivation; Bus $=$ businesses and informal Jobs; Job = regularly paid jobs; Ben = government benefits. Villages are shown from higher to lower reliance on fisheries and identified as Group 1 (red lettering) and Group 2 (green lettering). 1 = Barra do Ararapira; $2=$ Canudal; 3 = Poruquara; 4 = Guapicum; 5 = Vila das Peças; 6 =Tromomô; $7=$ Ilha Rasa; $8=$ Engenho Velho; $9=$ Massarapuã. 
TABLE 5 - Results of Spearman's correlation between total anual income, coefficient of income variation throughout the year, fisheries diversity, livelihood diversity and \% of income from fisheries. Statistical significant values are highlighted (** Significant correlation with $\mathrm{p}<0,01$ ).

\begin{tabular}{llcccc}
\hline & & Inc. var. & Fish. div. & Live. div. & \%inc. fish. \\
\hline Total anual income & Coefficient & $\mathbf{- . 3 7 8 ^ { * * }}$ & .064 & $\mathbf{. 4 9 1}^{* *}$ & $\mathbf{- . 2 0 0}^{* *}$ \\
Income variation & Coefficient & 1.000 & $\mathbf{. 3 4 8}^{* *}$ & $\mathbf{- . 3 1 7}^{* *}$ & $\mathbf{. 6 0 0}^{* *}$ \\
Fisheries diversity & Coefficient & $\mathbf{. 3 4 8 ^ { * * }}$ & 1.000 & .040 & $\mathbf{. 4 8 5}^{* *}$ \\
Livelihood diversity & Coefficient & $\mathbf{- . 3 1 7 ^ { * * }}$ & .040 & 1.000 & $-.288^{* *}$ \\
\hline
\end{tabular}

businesses and aquaculture are of little importance, and no households have regular paid jobs.

The analysis of correlations between income, income variation and livelihood diversity (Table 5) showed an inverse relation between total income and income variation, and a positive relation between total income and diversity of livelihood activities, but not with diversity of fisheries. Income variation was positively correlated with diversity of fisheries and negatively correlated with total livelihood activities. That is, a higher income and a greater diversity of livelihood activities were usually associated with lower income variation throughout the year, while diversification of fisheries alone did not result in lower income variation.

\subsection{The effect of MPAs on adaptation strategies according to levels of adaptive capacity}

Distribution of households into levels of adaptive capacity (Figure 6) followed the gradient of adaptive capacity identified in the multivariate analyses. The largest group of households (47\%) were those classified as having low adaptive capacity. Only $16 \%$ of households had high adaptive capacity, and these were concentrated mostly in Vila das Peças, while villages in Group 1 did not have any household with high adaptive capacity. Although most villages had households in all three levels, in Canudal and Engenho Velho all households had low adaptive capacity, while in Vila das Peças none of them were classified as such.

The comparison of the frequency of adaptation strategies outside of fisheries adopted (past/ present) and considered (future) by households with different levels of adaptive capacity is shown in Figures 7 and 8. Figure 7 shows the proportion of adopted and planned strategies, separating between those restricted by protected areas (R) and those benefited or with a neutral relation $(\mathrm{PN})$; Figure 8 divides the strategies among the major categories of income sources (cultivation, businesses, paid

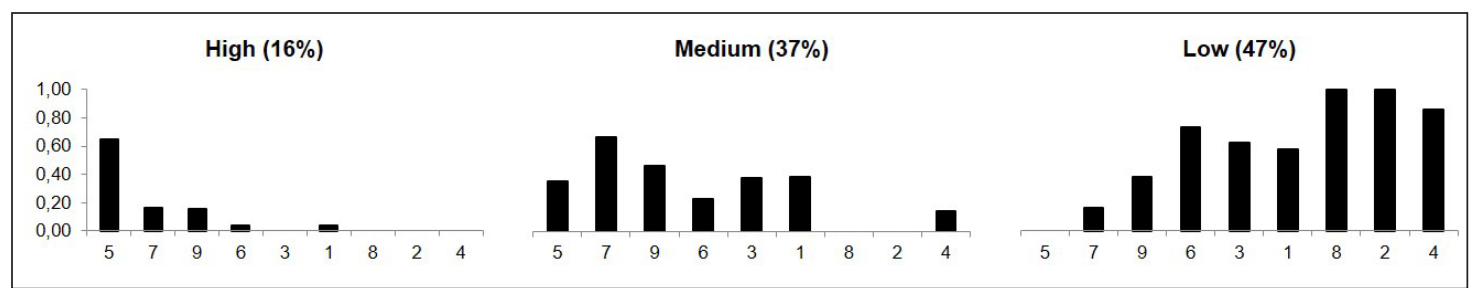

FIGURE 6 - Proportion of households in each level of adaptive capacity. Villages are shown from higher to lower adaptive capacity: 5=Vila das Peças; 7= Ilha Rasa; 9= Massarapuã; 6= Tromomô; 3= Poruquara; 1= Barra do Ararapira; 8= Engenho Velho; 2= Canudal; 4 = Guapicum. 


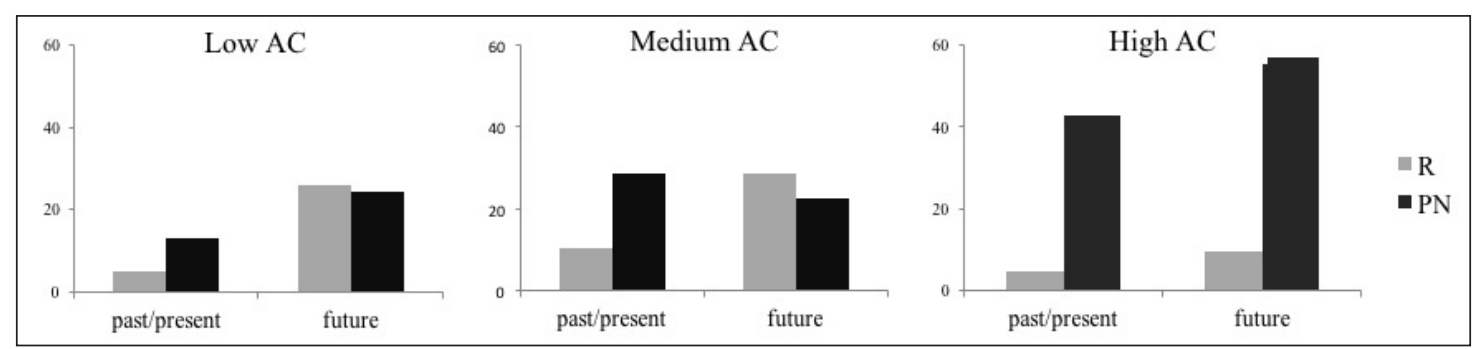

FIGURE 7 - Differences in occurence of livelihood diversification strategies according to the level of adaptive capacity (AC) and their relation with protected areas. $\mathrm{R}=$ restricted; $\mathrm{PN}=$ positive or neutral relation. Values in the $\mathrm{y}$-axis represent proportions of the total number of households in each level. Totals don't always add up to 100 because not all households have adopted or planned adaptation outside of fisheries.

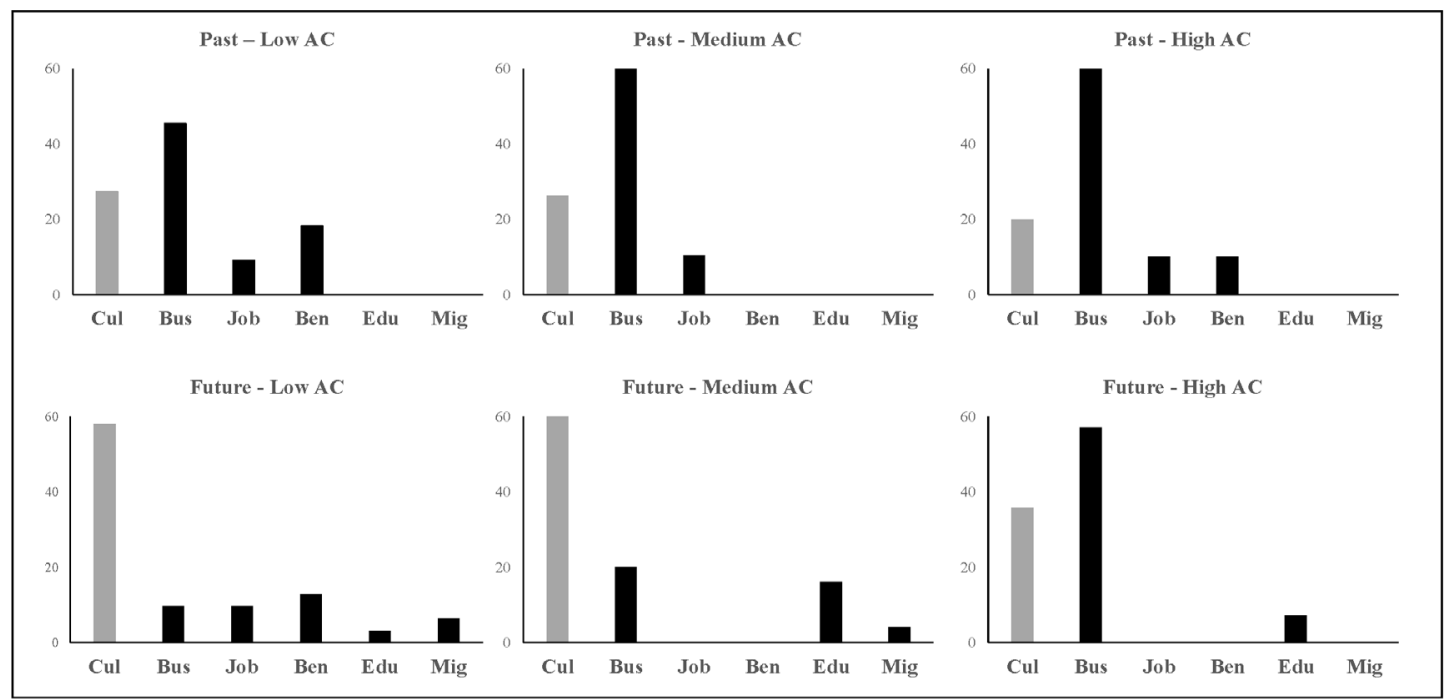

FIGURE 8 - Occurrence of adopted (past) and planned (future) livelihood diversification strategies according to the type of activity: $C u l=$ oyster cultivation (fish and prawn in some of the households); Bus= businesses, Job= regular paid job; Ben= government benefits; $E d u=$ seeking further education; $M i g=$ migrate/leave the village. Values on the y-axis represent proportions of the total number of strategies mentioned in each case.

jobs and governmental benefits), with the inclusion of two other categories: education and migration. In the past and present, around $50 \%$ of households with high adaptive capacity adopted diversification outside of fisheries, a proportion that fell to $39 \%$ in households with medium adaptive capacity, and only $18 \%$ among those with low adaptive capacity.

In the adopted strategies there was a predominance of businesses (mostly restaurants, small hotels and grocery stores) in all levels, but for the future, the most frequent strategy considered by households with medium and low adaptive capacity was oyster cultivation, which is restricted by MPAs, while those with high adaptive capacity continue to have businesses as their favoured diversification strategy. Among the strategies related with cultivation mentioned as a future option by households with high adaptive capacity, more than half of them were classified as having a positive or neutral relation with MPAs, because they consisted of fish 
or shrimp cultivation in villages located far from protected areas.

The alternative of finding a paid job appeared in a small proportion among the strategies already adopted, and as a future option was mentioned only by those with low adaptive capacity. Seeking further education and migrating were also less frequent, with the latter being mentioned only by households with low and medium adaptive capacity, and the former appearing in all three levels.

\section{Discussion and conclusions}

Communities and households showed heterogeneity in many of the factors that compose vulnerability to a decline in fisheries, with differences occurring along levels of the spatial scale and not following a single pattern. Diversification outside of fisheries is associated with less exposure to risk, but is not equally achievable by all households. There were differences between the types of strategy adopted in households, with the favoured strategy for households with low and medium adaptive capacity restricted by the existence of no-take protected areas. Results stress the need to consider differences in livelihoods and vulnerability when planning conservation and development actions. Regulation of livelihood activities inside protected areas is also needed, to reduce uncertainty and move from an open access situation into one where access rights are clearly regulated and the state of resources and ecosystems are evaluated and monitored, with the participation of stakeholders.

Following the sequence of the analysis described previously, main conclusions and their implications are:
4.1. Differences in key-components of sensitivity and adaptive capacity allowed for the recognition of two main groups of villages

Indicators related to physical capital (storage capacity and ownership of motorboats), social capital (level of participation in community organizations) and dependency on fisheries as an income source contributed the most to differences observed between the two groups of villages. These factors coincide with those commonly identified with generating vulnerability in coastal communities (Pomeroy et al., 2006). Although no significant differences were observed in income between villages, income inequality was observed inside villages. This reinforces the variability observed in vulnerability as a whole, as many of the factors that determined different levels of vulnerability are related to income.

Storage capacity and ownership of motorboats are related to income, but also to village infrastructure, which depends on government investment and can be restricted by protected areas. Households that are more reliant on fisheries and mangrove resources were located in villages that are small and lacking infrastructure. The lack of electricity in villages that rely on fisheries is a serious problem, as it limits the capacity to store catches and increases dependency on middlemen. The importance of this factor in determining differences in vulnerability stresses the need for investment in basic services and infrastructure, specially in more remote areas. Remoteness of villages was not considered beforehand as a determinant of vulnerability, but it influences many of the components of vulnerability that contributed to observed differences (Table 3). In addition to storage capacity, market connec- 
tions and the ability to seek further education are also influenced by remoteness and infrastructure. Considering that many of the remote villages are also those located near or inside protected areas, this should be considered whenever restrictions are imposed on development plans, such as the expansion of power grids and construction of educational facilities.

The level of participation in community organization, which was higher in villages with lower adaptive capacity, suggests that social capital can be important even in places that lack infrastructure and have lower income. Diversity of community organizations and the level of participation can be used as indicators of capacity to self-organize, one of the elements that theoretically compose resilience (Berkes \& Seixas, 2005). Many studies have identified social networks and informal institutions used by people in rural areas as relevant support to deal with crisis and disturbances (e.g. Osbahr et al., 2010). Because social capital is important in determining adaptation strategies (Pelling \& High, 2005), households in these villages could use this to counterbalance other characteristics which they lack. Community participation as a way of involving local stakeholders in the management of MPAs is promoted by the federal government in the region, through the establishment of advisory councils for the protected areas. Such councils can be an opportunity for these communities to enhance their influence on policy-making and reduce effects of conservation actions on their livelihoods.

Considering the variety of sources of income observed, it is important not to consider all rural livelihoods in the region as fisheries-based. The level of dependency on fisheries, measured by the proportion of income coming from this activity, varied from 34 to $69 \%$, and is similar to what has been observed in rural and coastal areas throughout the world (Ellis, 1998; Allison \& Ellis, 2001). With most households averaging less than $50 \%$ of their income from fisheries, a number that in 1998 varied from 55 to $82 \%$ (Borges et al., 2004), it seems that this activity has lost relative economic importance. In spite of this, for many households, specially in Canudal, Engenho Velho and Poruquara, fishing continues to be the main source of income, and has kept them above the poverty line. Other income sources are still of limited importance, and restricted to a few households in each village, with businesses and paid jobs concentrated on larger villages, with better infrastructure and access, such as Vila das Peças and Ilha Rasa. This may also be the result of a lack of alternatives for many of these households, which cannot seek livelihood diversification, due to lower adaptive capacity and to inadequate infrastructure in the villages.

\subsection{Livelihood diversification results}

in greater income, but is usually more accessible to those that are already better-off

Several factors influence the viability of livelihood diversification in the region, with the chance of a more diverse livelihood - with lower reliance on natural resources and higher income - being more accessible in villages that already have better services, infrastructure and connections with other areas. Furthermore, within these villages, diversification seems to be restricted to households with higher income.

The proportion of families classified as "poor" and "vulnerable", according to Brazilian national standards (IPEA, 2011), is higher in the studied villages than in the country. In spite of this, in most villages we found a small number of households with high income, standing above the national 
average. This inequality in income distribution leads us to a conclusion similar to Borges et al. (2004), that villages in the coast of Paraná are not poorer than the rest of the country. However, their social structure is a specific example of inequality and social exclusion that are still predominant in Brazilian society.

Income level is associated with diversification because those with lower income usually have a lower capacity to access external sources of funding, markets and job opportunities (Ellis, 1998; Ziervogel et al., 2006). They are also less prone to accept risk in the absence of some kind of safety net (Cinner et al., 2012). This was observed among fishers in Africa, where willingness to abandon a declining fisheries increased with income and livelihood diversity (Daw et al., 2012), and coincides with patterns observed in our study.

Diversification may result either in a reduction or an increase in inequality, working as a safety-net for the poor, but also as a means of wealth accumulation for the rich (Ellis, 1998), and income inequality will probably make collective-action adaptation projects less viable (Brouwer et al., 2007). Poorer households are also more prone to poverty-traps and cycles of increasing vulnerability, experiencing difficulties in recovering from impacts, which result in further impacts acting upon ever decreasing adaptive capacities (Brown \& Westaway, 2011).

Diversification is generally lower when required investment for activities is high (Allison \& Ellis, 2001). In Guaraqueçaba, there is little capital invested in the fishery and most gears are flexible and can be used in different fisheries. This brings mobility and the ability to diversify inside fisheries. However the limited ability of poor households to diversify outside of the fishery may indicate poverty-traps that limit their capacity to reduce risk from resource declines.
All non-fisheries activities correlated with higher income, but only pensions and paid jobs smoothed out income variation through steady income throughout the year. This can be explained by the reliance of commerce and tourism-related activities on disposable income of the village and the presence of visitors, both of which vary through the year. This has been observed in other studies with groups that depend on natural resources (e.g. Eriksen et al., 2005). The observed relation between income variation and diversification outside of fisheries confirms the theoretical prediction that diversifying is a useful strategy to reduce variability associated with natural resources (Ellis, 1998; Pomeroy et al., 2006) and strengthens the importance of this strategy in reducing vulnerability.

Educational level was one of the factors contributing to differences between the two groups of villages, and is frequently identified as a barrier for the poor to adopt alternatives such as regular paid jobs (e.g. Osbahr et al., 2008). In this region, seeking an education is further hindered by the lack of infrastructure in villages, with those places that showed higher proportion of households with low adaptive capacity also being more remote and having no educational facilities.

Considering the inequalities observed in the distribution of gears and boats, as well as in access to markets, further care must be taken when implementing actions that promote livelihood activities, such as mariculture (one of the favoured adaptation options) or even fisheries itself (e.g. funding to buy boats or build processing facilities), because these programs may contribute to maintaining or increasing inequalities, since those that are already better off usually are more capable of accessing benefits (Adger, 2006). The promotion of alternative income sources, such as tourism, is one of the benefits associated with the creation of protected areas, and 
is commonly suggested as a compensation for losses associated with restrictions to access rights. However, our results indicate that care is needed when implementing such programs, as the ability to take advantage of them is not equally distributed among households.

Most strategies adopted or considered by households coincide with activities that are already part of local livelihoods. The prevalence of shortterm alternatives, which may bring fast results, is typical of adaptation actions in many scenarios and can lead to long-term persistence of chronic vulnerability (Nelson et al., 2007). The main activities outside fisheries considered by local households - businesses and oyster cultivation - have the potential to generate income during periods when catches are lower and, therefore, reduce vulnerability to a further decline in catches. But, the presence of notake protected areas would affect the viability of these alternatives, if restricitions were to be applied indiscriminately to these populations.

\subsection{MPAs further restrict the options of those that already have lower adaptive capacity}

Reliance on mangrove resources was considered an indicator of adaptive capacity because most mangroves are located inside no-take protected areas, affecting the security of access rights. Access rights are important for vulnerability because they largely determine a group's capacity to cope and adapt to disturbances to their livelihoods (Adger \& Kelly, 1999).

Villages in Group 1, specialy Canudal and Engenho Velho, were the most reliant on mangrove resources, and also had all, or most, households with low adaptive capacity. Restrictions brought by no-take MPAs act on current livelihood activities, but also affect the adoption of adaptation strategies in the future. Oyster cultivation, the favoured option in households with low and medium adaptive capacity, is restricted by MPAs because oyster seeds are collected directly from mangroves. Thus, protected areas have a double negative effect on the livelihoods of those households considered most vulnerable, limiting both current activities and future adaptation options.

This distinct effect of protected areas on fishers livelihoods usually is determined, as was the case in Guaraqueçaba, by differences in target-species (Tuler et al., 2008), and can be related to a general tendency towards inequality in the distribution of costs and benefits of conservation actions. These inequalities occur between local and global contexts, but also inside villages, with members of well-off households usually being more able to access benefits, leaving most costs to others (Cinner et al., 2014, Coad et al., 2006). The positive effect of MPAs on the local economy usually comes from businesses associated with tourism. The prevalence of businesses as an adaption strategy for the future among households with high adaptive capacity exemplifies inequalities in distribution of costs and benefits. Therefore, restrictions brought by environmental rules, by reducing the flexibility of some livelihoods, become one of the major factors generating differences in vulnerability, even at the local scale (Ford et al., 2010).

Even when restrictions have not been enforced, as is the case in Guaraqueçaba, if these groups base their livelihoods in activities that are considered illegal, this must be correctly analyzed and managed. In such a context, options that require less adaptation, such as temporary closures of fishing sites and small changes in fishing tecnhiques may be more appropriate (Cinner et al., 2012), than having large areas permanently closed to any ex- 
tractive activity, a policy which the poorest groups will find hard to comply with. Establishing clear and secure access rights can lead to uses that guarantee long-term conservation of resources (Pomeroy et al., 2006), while total prohibition of access and enforcement of strict rules usually leads to free access and competition among users, resulting in the use of unsustainable techniques and over exlploitation, with a negative result on the resilience of the system (Adger, 2000; Lana, 2003).

Losing access rights will affect not only households, but can also have negative consequences on the village and regional levels, because fishing efforts may be displaced to other areas and resources, increasing competition and generating unequal losses, with those having lower adaptive capacity again facing higher costs and ending with higher vulnerability.

Resilience of the social-ecological system is also affected because total prohibition of resource use, if enforced, restricts the possibility of traditional knowledge about ecosystem and resource dynamics to evolve. This could affect these groups' capacity to learn, innovate and adapt formal and informal rules, in order to face environmental changes that inevitably will occur in natural systems (Adger, 2000; Almudi \& Kalikoski, 2009).

\subsection{Results point to the need for biodiversity conservation actions that are more flexible, adaptable and adequate to the local vulnerability context}

Differences observed in vulnerability and in the effects of protected areas on current livelihoods and future adaptation options show that livelihood diversification must be considered a very heterogeneous social and economic process. Recognizing this heterogeneity emphasizes the importance of investigating local contexts and adapting policies to their specific circumstances (Ellis, 1998). This type of analysis should take into account not only social and economic injustice associated with conservation actions, but also potential for mutual benefits for the social and the ecological systems (Chan et al., 2007). Seldom will conservation actions solve the problem of poverty and inequality, and this is probably not one of its main functions, but they can contribute in preventing and reducing poverty, if they guarantee ecosystem services and support local livelihoods (Naughton-Treves et al., 2005).

In Guaraqueçaba, insisting on unflexible and strict rules, may characterize a rigidity trap (Carpenter \& Brock, 2008), a situation where governmental agencies fail to adapt their policies and actions to the dynamics of the reality being managed. There are signs, though, that this is not the case, with initiatives such as the establishment of the advisory councils, and projects that aim to build comanagement of resource use, even inside no-take protected areas. Such initiatives take advantage of exceptions established by the Brazilian Protected Area Act (BRASIL, 2000), which guarantees access rights to groups of small-scale, subsistence users. These local arrangements can be considered part of the region's social capital, indicating a potential to build adaptive capacity through interactions between innovation that comes from informal relationships between users and managers, and order and formalism associated with bureaucratic management structures (Pelling \& High, 2005). A greater flexibility would favour persistence of local livelihoods and allow rules to keep in pace with the profound and uncertain changes expected on socialecological systems as a response to climate change.

In this region, flexibility could mean revising the level of protection of mangroves, transform- 
ing them into sustainable use protected areas, and involving resource users in policy-making and in monitoring of natural resources and management results. A possible obstacle to solutions that depend on community involvement is the low level of awareness showed by these populations regarding environmental rules. If restrictions imposed by protected areas are a threat to livelihoods, awareness about this threat and how to adapt to it is one of the main elements of adaptive capacity (Yohe $\&$ Tol, 2002), and is usually absent in this type of group (e.g. Cinner et al., 2009). The results of this study can contribute to enhancing awareness of resource-users and local managers and building solutions. In the next section we suggest other possible implications for management and adaptation policies and actions.

\section{Implications for management of fisheries and protected areas and adaptation to climate change}

Among solutions commonly prescribed to reduce vulnerability, many are related to the main problems found in this study, such as poverty reduction, promotion of livelihood diversification, maintenance of common property rights over resources or adequate compensation for losses, and incentives to collective action. These types of actions aim to guarantee to as many people as possible an adaptive capacity that allows responses to changes in natural systems and the persistence of livelihoods and social systems, instead of just short-term reaction to stress (Adger et al., 2004).

In this region, management of fisheries and protected areas should promote further involvement of resource users, guarantee access rights, seek flexibility of rules and adequately acknowledge unequal distribution of costs and benefits. Involvement of resource users would benefit from recognition of informal institutions already established for resource management, while access rights would be more secure with the establishment of a sustainable use approach in mangrove areas. Further studies in the region could aim to deepen knowledge about these informal institutions, generating useful information to help management agencies build comanagement arrangements.

Management and adaptation actions in the region should take into account the observed diversity of local livelihoods and of vulnerability both at the household and the village level. Promotion of livelihood diversification can partly compensate for losses resulting from conservation actions and help reduce vulnerability to declining fisheries, by increasing income and reducing income variation. However, development actions in the coast of Paraná will be more effective and adequate, if they consider existing differences in capacity and willingness to adopt diversification strategies. Livelihood diversification, while important to reduce vulnerability, doesn't necessarily mean completely abandoning fisheries. On the contrary, security brought by the inclusion of income sources that are not subject to the availability of natural resources can allow households to sustain a livelihood that includes fisheries and its cultural importance.

Additionaly, actions to promote alternatives shouldn't ignore reasons that lead fishers to remain in their activity and not seek diversification, and the existence of causes of vulnerability that act on different levels in society (Ribbot, 2011). For instance, the lack of infrastructute in villages, while being one of the main determinants of vulnerability, is something that cannot be solved by the local population, and should be among the priorities of local governments. On the other hand, local 
populations are already self-organizing to request changes in protected area's management regimes, a possibility that is recognized by the Brazilian Protected Area Act, should be adequately treated by local managers, and could reduce vulnerability by lifting restrictions on adaptation options envisaged by local households.

In summary, adequately recognizing how conservation actions impact local livelihoods synergistically with catch reductions and climate change, and recognising differences in vulnerability and adaptation options, can contribute to policies that are appropriate to the local context, that reduce inequality and that build resilience of fishers and the coastal ecosystems they rely on.

\section{Acknowledgements}

We thank the valuable help of Jose A. Fernandes and Leonardo Sandrini-Neto with statistical analysis and Tiago V. Mafra and Juliana O. Silva with fieldwork. Fieldwork was financed by a grant from Instituto HSBC Solidariedade. The first author was funded by ICMBIO and CAPES (Process BEX: 1423/11-8). Research inside protected areas was authorized by ICMBIO (Sisbio Authorization number 24705-1).

\section{References}

Adams, W. M.; Hutton, J. People, parks and poverty: political ecology and biodiversity conservation. Conservation and Society, 5(2), 147-183, 2007.

Adger, W. N. Social and ecological resilience: are they related? Progress in Human Geography, 24(3), 347-364, 2000.

Adger, W. N. Vulnerability. Global Environmental Change, 16, 268-281, 2006.

Adger, W. N.; Brooks, N.; Bentham, G.; Agnew, M.; Eriksen, S. New indicators of vulnerability and adaptive capacity. Rep. 7, Tyndall Cent. Clim. Change Res., Norwich, UK, 2004. Available at: $<$ http://www.tyndall.ac.uk/publications/ pub_list_2004.shtml $>$.

Adger, W. N.; Kelly, P. M. Social vulnerability to climate change and the architecture of entitlements. Mitigation and Adaptation Strategies for Global Change, 4(3-4), 253-266, 1999.

Allison, E. H.; Ellis, F. The livelihoods approach and management of small-scale fisheries. Marine Policy, 25(5), 377-388, 2001.

Allison, E. H.; Perry, A. L.; Badjeck, M-C.; Adger, W. N.; Brown, K.; Conway, D.; Halls, A. S.; Pilling, G. M.; Reynolds, J. D.; Andrew, N. L.; Dulvy, N. K. Vulnerability of national economies to the impacts of climate change on fisheries. Fish and Fisheries, 2009. doi: 10.1111/j.1467-2979.2008.00310.x.

Almudi, T.; Kalikoski, D. C. Homem e "natureza" em um parque nacional do sul do Brasil: meios de vida e conflitos nos arredores da Lagoa do Peixe. Desenvolvimento e Meio Ambiente (UFPR), 20, 1-12, 2009.

Anderson, M. J. A new method for non-parametric multivariate analysis of variance. Austral Ecol, 26, 32-46, 2001.

Andriguetto-Filho, J. M. Institutional prospects in managing coastal environmental conservation units in Paraná State, Brazil. Eighth Syposium on Coastal and Ocean Management, New Orleans. Zone '93 proceedings - ASCE, 23542368, 1993.

Andriguetto-Filho, J. M. Sistemas técnicos de pesca no litoral do Paraná: caracterização e tipificação. In: Raynaut, C.; Zanoni, M.; Lana, P. C.; Floriani, D.; Ferreira, A. D. D.; Andriguetto-Filho, J. M. (Ed.). Em busca da interdisciplinaridade: pesquisas urbanas e rurais. Curitiba: UFPR, 295p. 2002. p. 213-233.

Andriguetto-Filho, J. M. A mudança técnica e o processo de diferenciação dos sistemas de produção pesqueira do Litoral do Paraná, Brasil. Desenvolvimento e Meio Ambiente, 8, 43-58, 2003. 
Andriguetto-Filho, J. M.; Chaves, P. T.; Santos, C.; Liberati, S. A. Diagnóstico da pesca no litoral do estado do Paraná. In: Isaac, V. J.; Martins, A. S.; Haimovici, M.; Andriguetto-Filho, J. M. (Ed.). A pesca marinha e estuarina do Brasil no início do século XXI: recursos, tecnologias, aspectos socioeconômicos e institucionais. Belém: Editora Universitária da UFPA, 2006. p. 117-140.

Badjeck, M-C.; Allison, E. H.; Halls, A. S.; Dulvy, N. K. Impacts of climate variability and change on fishery-based livelihoods. Marine Policy, 34, 375-383, 2010.

Berkes, F.; Seixas, C. S. Building resilience in lagoon socialecological systems: a local-level perspective. Ecosystems, 8, 967-974, 2005.

Borges, L. M. M.; Maulin, G. C.; Andriguetto, J. M. Analysis of income sources of fishers' families on the coast of the State of Paraná, Brazil. Journal of Coastal Research, Special Issue 39, 1267-1271, 2004.

Brasil. Lei $n^{\circ}$ 9.985, de 18 de julho de 2000. Regulamenta o art. 225, $\S 1^{\circ}$, incisos I, II, III e VII da Constituição Federal, institui o Sistema Nacional de Unidades de Conservação da Natureza e dá outras providências. Available online at: $<$ http://www.planalto.gov.br/ccivil_03/leis/L9985.htm>.

Brooks, N.; Adger, W. N. Assessing and enhancing adaptive capacity. In: Lim, B.; Spanger-Siegfried, E. (Eds.). Adaptation policy frameworks for climate change: developing strategies, policies and measures. UNDP-GEF. Cambridge University Press, 2005. p. 165-181.

Brouwer, R.; Akter, S.; Brander, L.; Haque, E. Socioeconomic vulnerability and adaptation to environmental risk: a case study of Climate Change and flooding in Bangladesh. Risk Analysis, 27(2), 2007. doi: 10.1111/j.15396924.2007.00884.x

Brown, K.; Westaway, E. Agency, capacity, and resilience to environmental change: lessons from human development, well-being, and disasters. Annu. Rev. Environ. Resour., 36, 14.1-14.22, 2011.

Carpenter, S. R.; Brock, W. A. Adaptive capacity and traps. Ecology and Society, 13(2), art. 40, 2008. Available online at: $<$ http://www.ecologyandsociety.org/vol13/iss2/art40/>.

Cernea, M. M.; Schmidt-Soltau, K. Poverty risks and national parks: policy issues in conservation and resettlement. World Development, 34(10), 1808-1830, 2006.
Chambers, R.; Conway, G. R. Sustainable rural livelihoods: practical concepts for the 21 st century. IDS Discussion Paper 296, 1992.

Chan, K. M. A.; Pringle, R. M.; Ranganathan, J.; Boggs, C. L.; Chan, Y. L.; Ehrilch, P. R.; Haff, P. K.; Heller, N. E.; Al-Khajafi, K.; MacMynowski, D. P. When agendas collide: human welfare and biological conservation. Conservation Biology, 21(1), 59-68, 2007.

Cheung, W. W. L.; Lam, V. W. Y.; Sarmiento, J. L.; Kearney, K.; Watson, R.; Zeller, D.; Pauly, D. Large-scale redistribution of maximum fisheries catch potential in the global ocean under climate change. Global Change Biology, 16, 24-35, 2010. doi: 10.1111/j.1365-2486.2009.01995.x

Cinner, J. E.; Daw, T.; McClanahan, T. R. Socioeconomic factors that affect artisanal fishers' readiness to exit a declining fishery. Conservation Biology, 23, 124-130, 2009.

Cinner, J. E.; McClanahan, T. R.; Graham, N. A. J.; Daw, T. M.; Maina, J.; Stead, S. M.; Wamukota, A.; Brown, K.; Bodin, Ö. Vulnerability of coastal communities to key impacts of climate change on coral reef fisheries. Global Environmental Change, 22(1), 12-20, 2012.

Cinner, J. E.; Daw, T.; Huchery, C.; Thoya, P.; Wamukota, A.; Cedras, M.; Abunge, C. Winners and Losers in Marine Conservation: Fishers' Displacement and Livelihood Benefits from Marine Reserves. Society \& Natural Resources, 27, 994-1005. 2014.

Cinner, J. E.; Huchery, C.; Hicks, C. C.; Daw, T. M.; Marshall, N.; Wamukota, A.; Allison, E. H. Changes in adaptive capacity of Kenyan fishing communities. Nature Clim. Change, 5, 872-876, 2015.

Clarke, K. R. Non-parametric multivariate analyses of changes in community structure. Australian Journal of Ecology, 18, 117-143, 1993.

Coad, L.; Campbell, A.; Miles, L.; Humphries, K. The costs and benefits of Protected Areas for local livelihoods: a review of the current literature. Working Paper. UNEP World Conservation Monitoring Centre, Cambridge, U.K., 2008.

Daw, T. M.; Cinner, J. E.; McClanahan, T. R.; Brown, K.; Stead, S. M.; Graham, N. A. J.; Maina, J. To Fish or Not to Fish: Factors at Multiple Scales Affecting Artisanal Fishers' Readiness to Exit a Declining Fishery. PLoS ONE 7, e31460, 2012. 
Dudley, N. (Ed.). Guidelines for Applying Protected Area Management Categories. Gland, Switzerland: IUCN, 2008.

Ellis, F. Household strategies and rural livelihood diversification. The Journal of Development Studies, 35(1), 1-38, 1998.

Ellis, F. The determinants of rural livelihood diversification in developing countries. Journal of Agricultural Economics, 51(2), 289-302, 2000.

Eriksen, S. H.; Brown, K.; Kelly, P. M. The dynamics of vulnerability: locating coping strategies in Kenya and Tanzania. The Geographical Journal, 171(4), 287-305, 2005.

Fernandes, J. A.; Irigoien, X.; Goikoetxea, N.; Lozano, J. A. Fish recruitment prediction, using robust supervised classification methods. Ecological Modelling, 221, 338-352, 2010.

Ford, J. D.; Keskitalo, E. C. H.; Smith, T.; Pearce,T.; Berrang-Ford, L.; Duerden, F.; Smit, B. Case study and analogue methodologies in climate change vulnerability research. WIREs Climate Change, 1, 374-392. doi: 10.1002/ wcc. 48

Fundação SOS Mata Atlântica; INPE - Instituto Nacional de Pesquisas Espaciais. Atlas dos remanescentes florestais de Mata Atlântica: período 2013-2014. Relatório Técnico. São Paulo, 2015. Available at: $<$ http://mapas.sosma.org.br> .

Hahn, M. B.; Riederer, A. M.; Foster, S. O. The livelihood vulnerability index: a pragmatic approach to assessing risks from climate variability and change. A case study in Mozambique. Global Environmental Change, 19(1), 74-88, 2009.

IBGE - Instituto Brasileiro de Geografia e Estatística. Censo demográfico 2010 - Características da população e dos domicílios - Resultados do universo. Rio de Janeiro: IBGE, 2011.

IPARDES - Instituto Paranaense de Desenvolvimento Econômico e Social. Caderno estatístico do município de Guaraqueçaba. IPARDES, Online report, 2016. Available at: <http://www.ipardes.gov.br/cadernos/Montapdf. php?Municipio $=83390>$.

IPÊ - Instituto de Pesquisas Ecológicas. Nas malhas da inclusão - subsídios para implantação do Plano de Gestão Participativa da Pesca na APA de Guaraqueçaba/PR. Relatório técnico final. Convênio Ministério da Pesca e Aquicultura. Nazaré Paulista - SP, 2011.
IPEA - Instituto de Pesquisa Econômica Aplicada. Mudanças recentes na pobreza brasileira. Comunicados do IPEA, 111, Brasília/DF, 2011.

Kalikoski, D. C.; Quevedo Neto, P.; Almudi, T. Building adaptive capacity to climate variability: the case of artisanal fisheries in the estuary of the Patos Lagoon, Brazil. Marine Policy, 2010. doi: 10.1016/j.marpol.2010.02.003

Kelly, P. M.; Adger, W. N. Theory and practice in assessing vulnerability to climate change and facilitating adaptation. Clim. Change, 47, 325-352, 2000.

Lam, M. E.; Pauly, D. Who is right to fish? Evolving a social contract for ethical fisheries. Ecology and Society, 15(3), art. 16, 2010. Avaliable at: $<$ http://www.ecologyandsociety. org/vol15/iss3/art16/>.

Lana, P. C. Manguezais, legislação e gestão de áreas costeiras: o caso da Baía de Paranaguá. In: Vieira, P. F. (Ed.). Conservação da diversidade biológica e cultural em zonas costeiras. Florianópolis: Aped, 2003. p. 313-331.

Lana, P. C.; Marone, E.; Lopes, R. M.; Machado, E. C. The subtropical estuarine complex of Paranaguá Bay, Brazil. Ecol. Stud., 144, 131-145, 2001.

Luers, A. L.; Lobell, D. B.; Sklar, L. S.; Addams, C. L.; Matson, P. A. A method for quantifying vulnerability, applied to the agricultural system of the Yaqui Valley, Mexico. Global Environmental Change, 13(4), 255-267, 2003.

Marengo, J. A.; Valverde, M. C. Caracterização do clima no século XX e cenário de mudanças de clima para o Brasil no século XXI usando os modelos do IPCC-AR4. Revista Multiciência, 8, 5-28, 2007.

Miranda, R. B. Dinâmicas de apropriação e saberes comunais dos manguezais e de seus recursos bênticos de interesse econômico no complexo estuarino da baía de Paranaguá, Paraná. Curitiba, Tese (Doutorado em Meio Ambiente e Desenvolvimento) - UFPR, 2004.

Myers, N.; Mittermeier, R. A.; Mittermeier, C. G.; Fonseca, G. A. B.; Kent, J. Biodiversity hotspots for conservation priorities. Nature, 403, 853-858, 2000.

Naughton-Treves, L.; Holland, M. B.; Brandon, K. The role of protected areas in conserving Biodiversity and sustaining local Livelihoods. Annu. Rev.Environ. Resour., 30, 219-252, 2005. 
Nellemann, C.; Hain, S.; Alder, J. In dead water: merging of climate change with pollution, over-harvest, and infestations in the world's fishing grounds. Norway: United Nations Environment Programme, GRID-Arendal, 2008.

Nelson, D. R.; Adger, W. N.; Brown, K. Adaptation to environmental change: contributions of a resilience framework. Annu. Rev. Environ. Resour., 32, 395-419, 2007.

Osbahr, H.; Twyman, C.; Adger, W. N.; Thomas, D. S. G. Effective livelihood adaptation to climate change disturbance: scale dimensions of practice in Mozambique. Geoforum, 39, 1951-1964, 2008.

Osbahr, H.; Twyman, C.; Adger, W. N.; Thomas, D. S. G. Evaluating successful livelihood adaptation to climate variability and change in southern Africa. Ecology and Society, 15(2), art. 27. Available online at: $<$ http://www. ecologyandsociety.org/vol15/iss2/art27/. 2010>.

Pelling, M.; High, C. Understanding adaptation: What can social capital offer assessments of adaptive capacity? Global Environmental Change, 15, 308-319, 2005.

Pomeroy, R. S.; Ratner, B. D.; Hall, S. J.; Pimoljinda, J.; Vivekanandan,V. Coping with disaster: rehabilitating coastal livelihoods and communities. Marine Policy, 30, 786-793, 2006.

Pörtner, H.-O.; Karl, D. M.; Boyd, P. W.; Cheung, W. W. L.; Llucha-Cota, S. E.; Nojiri, Y.; Schmidt, D. N.; Zavialov, P. O. 2014: Ocean Systems. In: Field, C. B.; Barros, V. R.; Dokken, D. J.; Mach, K. J.; Mastrandrea; M. D.; Bilir, T. E.; Chatterjee, M.; Ebi, K. L.; Estrada, Y. O.; Genova, R. C.; Girma, B.; Kissel, E. S.; Levy, A. N.; MacCracken, S.; Mastrandrea, P. R.; White, L. L (Eds.). Climate Change 2014: Impacts, Adaptation, and Vulnerability. Part A: Global and sectoral aspects. Contribution of Working Group II to the Fifth Assessment Report of the Intergovernmental Panel on Climate Change. Cambridge and New York: Cambridge University Press, 2014. p. 411-484.
Ribbot, J. Vulnerability before adaptation: toward transformative climate action. Global Environmental Change, 21, 1160-1162, 2011.

Schwarz, A-M.; Béné, C.; Bennett, G.; Boso, D.; Hully, Z.; Paul, C.; Posala, R.; Sibiti, S.; Andrew, N. Vulnerability and resilience of remote rural communities to shocks and global changes: Empirical analysis from Solomon Islands. Global Environmental Change, 21, 1128-1140, 2011.

Teixeira, C. O desenvolvimento sustentável em unidades de conservação: a "naturalização" do social. Rev. Bras. Ci. Soc. [online], 20(59), 51-66, 2005. ISSN 18069053. Available at: <http://dx.doi.org/10.1590/S010269092005000300004>.

Thomas, H. L.; MacSharry, B.; Morgan, L.; Kingston, N.; Moffitt, R.; Stanwell-Smith, D.; Wood, L. Evaluating official marine protected area coverage for Aichi Target 11: appraising the data and methods that define our progress. Aquatic Conserv: Mar. Fresh. Ecosyst., 24(2), 8-23, 2014.

Tuler, S.; Agyeman, J.; da Silva, P.P.; LoRusso, K. R.; Kay, R. Assessing vulnerabilities: integrating information about driving forces that affect risks and resilience in fishing communities. Human Ecology Review, 15, 171-184, 2008.

UNDP - United Nations Development Program. Human Development Indicators 2003. Human Development Report Office, United Nations Development Programme, 2003.

Yohe, G.; Tol, R. Indicators for social and economic coping capacity - moving toward a working definition of adaptive capacity. Global Environmental Change, 12, 25-40, 2002.

Zanoni, M.; Ferreira, A. D. D.; Miguel, L. A.; Floriani, D.; Canali, N.; Raynaut, C. The preservation of nature and rural development: dilemmas and strategies of family farmers in Areas of Environmental Protection. Desenvolvimento e Meio Ambiente, 2, 39-55, 2000.

Ziervogel, G.; Bharwani, S.; Downing, T. E. Adapting to climate variability: Pumpkins, people and policy. Natural Resources Forum, 30, 294-305, 2006. 